\title{
Evaluasi Pelatihan Otomotif Dalam Meningkatkan Keterampilan Peserta Didik Di UPT-BLK Palangka Raya
}

\author{
Wahidin, Kusnida Indrajaya, Mardiana, Santi Matondang, Giovani \\ Sibarani \\ Program Studi Pendidikan Luar Sekolah, Fakultas Keguruan Dan Ilmu \\ Pendidikan, Universitas Palangka Raya, Indonesia. \\ Email: wahidin@pls.upr.ac.id
}

Diterima: 28-10-2021; Diperbaiki:08-02-2022; Disetujui:09-02-2022

\begin{abstract}
ABSRTAK
Penelitian ini bertujuan untuk mengevaluasi pelatihan otomotif pada tahun 2021 yang dilaksanakan di UPT-BLK Palangka Raya. Kegiatan utama yang dilakukan berhubungan dengan proses pelaksanaan pelatihan, kendala yang dihadapi dan bagaimana hasil pelatihan yang berhubungan dengan kelulusan dari peserta pelatihan. Penelitian ini menggunakan pendekatan kualitatif dengan mengacu pada pendapat Moleong, bahwa penelitian kualitatif bermaksud untuk memahami fenomena tentag apa yang dialami oleh peserta didik, dalam hal ini observasi langsung terhadap kegiatan pelatihan otomotif yang diselenggarakan di UPT-BLK Palangka Raya pada tahun 2021. Prosedur pengumpulan data dengan observasi, wawancara dan dokumentasi. Proses analisis dilakukan sejak awal dilapangan dan selesai dilapangan dengan analisis data model Miles Hubermen. Hasil pelaksanaan penelitian dilihat dari perencanaan, pengorganisasian, pengarahan dan pengendalian dalam kegiatan pelatihan. Perencanaan penelitian dimulai dari persiapan sosialisasi, pendaftaran peserta, pelaksanaan tes, pengumuman kelulusan, dilakukan secara daring mengingat masih dalam suasana pandemi covid 19. Selanjutnya instruktur menyiapakan kurikulum dan perangkat pembelajaran sesuai ketentuan. Pengorganisasian pelatihan otomotif dilakukan dengan menggunakan media komunikasi dengan membuat group whatsapp untuk memudahkan komunikasi. Pengarahan dilakukan pada proses pelaksanaan pelatihan tatap muka dengan memperhatikan protokol kesehatan. Pengendalian pelatihan ini dengan monitoring langsung dari pimpinan UPT-BLK Palangka Raya dan dari pimpinan wilayah Samarenda. Sedangkan kendala yang dihadapi selama pelatihan adalah sebagian peralatan pelatihan sudah lama sehingga perlu peralatan baru. Sedangkan hasil pelatihan otomotif di UPT-BLK Palangka Raya pada tahun 2021 cukup baik yakni mencapai $80 \%$ dari seluruh peserta.

Kata Kunci: evaluasi, keterampilan, otomotif, pelatihan
\end{abstract}




\section{PENDAHULUAN}

Upaya mengembangkan potensi diri ini tidak saja dapat ditempuh melalui jalur pendidikan formal, tetapi juga melalui jalur pendidikan nonformal dan informal. Pendidikan formal adalah jalur pendidikan yang terstruktur dan berjenjang yang terdiri atas pendidikan dasar, pendidikan menengah, dan pendidikan tinggi. Pendidikan non formal adalah jalur pendidikan di luar jalur pendidikan formal yang dapat dilaksanakan secara terstruktur dan berjenjang. Sedangkan pendidikan informal adalah jalur pendidikan keluarga dan lingkungan disebutkan dalam Undang-Undang Ripublik Indonesia tentang Sistem Pendidikan Nasional tahun 2003. Pendidikan masyarakat dapat dilaksanakan melalui satuan pendidikan nonformal yang menyelenggarakan kegiatan keaksaraan, pendidikan kesetaraan, pendidikan anak usia dini, pendidikan kecakapan hidup, pendidikan keterampilan atau kursus, pelatihan kerja, serta pendidikan lain yang ditunjukan untuk mengembangkan kemampuan peserta didik.

Unit Pelaksana Teknis Badan Latihan Kerja umumnya melaksanakan kegiatan-kegiatan yang diperuntukan bagi masyarakat umum. Program pelatihan otomotif salah satu ranah pendidikan non formal yang ada di UPT-BLK Palangka Raya, dimana keberadaannya diharapkan memberi dampak positif dalam meningkatkan kualitas SDM yang diarahkan untuk menjawab tantangan kebutuhan dunia kerja di era globalisasi sekarang ini. Adapun program yang di laksanakan di UPT-BLK adalah produksi furniture, administrsi perkantoran, menjahit, boga, perbaikan AC, Las, otomotif, pengoperasian bubut, operator kumputer. Dengan banyaknya program yang di lakukan UPT-BLK penelitian berfokus pada satu program yaitu otomotif.

Permasalahan yang terjadi selama ini adalah banyaknya stok tenaga kerja yang tidak sesuai dengan lapangan pekerjaan yang tersedia, sehingga menimbulkan banyaknya pengangguran di berbagai tingkat lulusan pendidikan. Hal ini merupakan masalah sosial yang harus diatasi bagi pengambil kebijakan. Oleh karena itu, maka perlu membekali tenaga kerja dengan skill atau keterampilan yang dibutuhkan oleh masyarakat saat ini yang sesuai dengan perkembangan zaman.

Dalam penelitian ini penting mengevaluasi pelatihan otomotif yang dilakukan UPT-BLK Palangka Raya yang selama ini proses pelatihan sudah di lakukan dengan baik, namun mungkin banyak permasalahan yang masih di hadapi. Dengan keterbatasan dari kemampuan yang dimiliki penyelenggaraan pelatihan.

Berdasarkan hasil dari wawancara dengan staf tata usaha UPT-BLK Palangka Raya, evaluasi pelatihan otomotif perlu dilakukan guna untuk melihat bagaimana kelancaran pelatihan berlangsung dan apa permasalahannya serta bagaimana hasilnya guna memperbaiki kualitas pelatihan berikutnya. Penelitian ini bertujuan untuk mengetahui, 1) Bagaimana pelaksanaan pelatihan, 2) Apa kendala pelaksanaan pelatihan, dan 3) Bagaimana hasil pelatihan otomotif di UPT - BLK Palangka Raya. 


\section{METODOLOGI PENELITIAN}

Penelitian ini dilakukan dengan pendekatan kualitatif, penelitian di sajikan dengan data uraian kata-kata berdasarkan hasil yang di temui di lapangan. Penelitian kualitatif di lakukan secara rinci dengan cara pengamatan fenomena atau kejadian untuk mencari tahu jawaban sehingga jawaban tersebut benar-benar memuaskan.

Penelitian ini di lakukan di Unit Pelaksana Teknis Balai Latihan Kerja (UPTBLK) Palangka Raya Jl. Tjilik Riwut Km 5. Dengan alasan memilih lokasi ini karena pada saat pandemi sekarang ini banyak institusi yang tidak dapat melaksanakan pelatihan terkait protokol kesehatan. Sedangkan UPT-BLK Palangka Raya dapat melaksanakan pelatihan sesuai dengan protokol kesehatan yang benar.

Penelitian ini menggunakan instrumen penelitian angket yang telah dikembangkan dan telah divalidasi. Oleh karena itu, pengumpulan data yang digunakan dengan tehnik observasi, wawancara, dan dokumentasi. Proses analisis data dalam penelitian kualitatif dilakukan sejak sebelum memasuki lapangan, selama di lapangan, dan setelah selesai di lapangan. Pengecekan Keabsahan Data: Uji Kredibilitas (Credibility) Transferabilitas (Transferability), Dependabilitas (Dependability ), dan Konfirmabilitas (Confirmability).

\section{HASIL DAN PEMBAHASAN PENELITIAN \\ Pelaksanaan Pelatihan Otomotif}

Berdasarkan pada hasil penelitian ditemukan bahwa pendaftaran pelatihan otomotif di laksanakan secara online, tes tertulis berbasis kumputer dan tes wawancara untuk mengetahui minat calon peserta didik. Instruktur/tutor menyiapkan metode pelatihan dan menyusun jadwal kegiatan pelatihan, dengan kegiatan yang dilaksanakan secara tatap muka dengan tetap mematuhi protokol kesehatan seperti, mencuci tangan, memakai masker dan menjaga jarak.

Program pelatihan otomotif di UPT-BLK Palangka Raya merupakan salah satu bagian dari program pelatihan yang lain. Dalam pelatihan otomotif ini peserta di latih supaya mampu menguasai dalam bidang perbengkelan. Bukan hanya menguasai saja, melainkan peserta didik juga diharapkan mampu menerapkan dan mengembangkan keterampilan mereka dalam dunia kerja.

Pelatihan ini diberikan guna meningkatkan sumber daya manusia yang ada di kota Palangka Raya pada khususnya. Memberikan keterampilan untuk masyarakat adalah salah satu upaya untuk membantu mengurangi tingkat pengangguran dan juga membatu masyarakat untuk lebih mandiri dalam membuka usaha sendiri. Keterampilan saat ini merupakan sesuatu yang sangat penting yang harus dimiliki setiap orang.

Dalam pelaksanaan pelatihan otomotif instruktur/tutor memberikan materi dan peserta melakukan prakteknya. Namun tidak hanya itu saja, instruktur membantu dan mendorong peserta yang kurang memahami atau bahkan sulit untuk 
memahami pada saat praktek. Peserta dibimbing dengan sebaik mungkin untuk menciptakan lulusan yang berkualitas.

Pelaksanaan pelatihan otomotif di UPT-BLK Palangka Raya berlangsung dari bulan Maret-April tahun 2021 dengan waktu 280 jp atau juga kurag lebih satu bulan kegiatan. Peserta didik/warga belajar yang mengikuti pelatihan otomotif ini berjumlah 16 (enam belas) orang sesuai dengan jumlah yang sudah ditentukan oleh dinas ketenagakerjaan. Instruktur pelatihan otomotif berjumlah 1 (satu) orang.

\section{Kendala Pelaksanaan Pelatiahan}

Akibat dari kemampuan dasar yang dimiliki peserta pelatihan tidak sama sehingga menimbulkan kendala untuk memberikan pelatihan yang sesuai, karena pelatihan yang diberikan sesuai dengan standar kurikulum yang berlaku. Kendala yang lain dihadapi adalah beberapa peralatan sudah mulai rusak akibat sikap kerja peserta pelatihan yang tidak terarah. Ada juga mesin praktik yang sudah tua dengan perbaikan yang begitu besar sehingga tidak termasuk dalam anggaran dana pembiayaan pelatihan.

Kendala yang dialami dalam pengorganisasian pelaksanaan pelatihan ini adalah instruktur yang tersedia hanya satu orang, kekurangan tenaga instruktur ini sangat berdampak pada manejemen pelatihan dengan jumlah yang tidak sedikit, apalagi kondisinya dimasa pandemi sekarang ini. Pengelolaan kelas sangat menentukan keberhasilan pembelajaran.

\section{Hasil Pelaksanaan Penelitian}

Hasil dari pelaksanaan pelatihan otomotif di UPT-BLK Palangka Raya kelulusan $80 \%$. Beberapa peserta tidak lulus dalam pelatihan otomotif ini di karenakan faktor kehadiran dan sikap yang mereka lakukan semasa kegiatan pelatihan berlangsung. Dengan kelulusan $80 \%$ peserta maka pelatihan ini termasuk berhasil dengan baik.

\section{KESIMPULAN}

Instruktur, sarana dan prasarana, materi, jadwal pelatihan dan metode telah menunjang pelaksanaan pelatihan. Pengendalian kegiatan pelatihan atau monitoring evaluasi dilaksanakan oleh pihak atasan langsung dalam hal ini pimpinan UPT-BLK Palangka Raya yang dilaksanakan secara berkala untuk menjamin ketercapaian tujuan pelaksanaan pelatihan. Kendala yang dihadapi adalah latar belakang peserta tidak sama, maka menimbulkan kendala untuk menyajikan pelatihan yang sesuai, selain itu beberapa peralatan sudah mulai rusak, mesin praktik yang sudah tua, dan kurangnya biaya perbaikan. Kendala dalam pengorganisasian instruktur otomotif masih kurang sangat berdampak pada manejemen pelatihan apalagi kondisi dimasa pandemi covid 19. Hasil dari pelaksanaan pelatihan otomotif di UPT-BLK Palangka Raya kelulusan 80\%. 
Beberapa peserta tidak lulus dalam pelatihan otomotif ini di karenakan faktor kehadiran dan sikap yang mereka lakukan semasa kegiatan pelatihan berlangsung.

\section{DAFTAR PUSTAKA}

Depdiknas. 2003. Undang-Undang Republik Indonesia Nomor 20 Tahun 2003, tentang Sistem Pendidikan Nasional. Jakarta: Cipta Jaya

Kamil, Mustofa. 2010. Model Pendidikan dan Pelatihan Konsep dan Aplikasi. Bandung: Penerbit Alfabeta

Kamil, Mustofa. 2011. Pendidikan Nonformal Pengembangan Melalui Pusat Kegiatan Belajar Mengajar (PKBM) di Indonesia (Sebuah Pembelajaran dari Kominkan Jepang). Bandung: Alfabeta.

Mayang. 2013. Pelaksanaan Pelatihan Keterampilan otomotif sepeda Motor Dalam Meningkatkan Kemandirian Remaja Di Balai Latihan Kerja (BLK) Kota Palangkaraya. Universitas Palangkaraya.

Moleong, Lexy, J. 2002. Metodologi Penelitian Kualitatif. Bandung: Remaja Rosdakarya.

Mustofa, Kamil. 2010. Model Pendidikan dan Pelatihan. Bandung: Alfabeta

Marzuki, Saleh. 2010. Pendidikan Non Formal. (Dimensi dalam Keaksaraan Fungsional, Pelatihan, dan Andragogi. Bandung: PT. Remaja Rosdakarya

Moleong, Lexy J. 2009. Metode Penelitian Kualitatif. Edisi Revisi. Bandung: PT. Remaja Rosdakarya.

Moleong, Lexy. 2007. Metodologi Penelitian Kualitatif. Bandung: Remaja Karya. Moleong, Lexy, J. 2009. Metodologi Penelitian Kualitatif. Edisi Revisi. Bandung: Remaja Rosdakarya.

Miles, B. Matthew dan Huberman., A. Michael., Saldana, Johnny. 2014. Analisis Data Kualitatif. Buku Sumber Tentang Metode-Metode Baru. Jakarta: UIPRESS.

Moleong, L.J. 2001. Metodologi Penelitian Kualitatif. Bandung: Remaja Rosdakarya.

Nasution. 2009. Metode Research (Penelitian Ilmiah). Jakarta : Bumi Aksara.

Nasution. 2006. Berbagai Pendekatan Dalam Proses Belajar Mengajar. Jakarta: Bumi Aksara.

Sumantri. 2000. Pelatihan dan Pengembangan Sumber Daya Manusia (SDM). Bandung: Fak.Psikologi, Unpad.

Sudjana, H.D. 2007. Sistem dan Manajemen Pelatihan Teori dan Aplikasi. Bandung: Falah Production.

Sutarto, Joko. 2007. Pendidikan Non Formal (Konsep Dasar, Proses Pembelajaran, \& Pemberdayaan Masyarakat). Semarang: Universitas Negeri Semarang Press.

Sugiyono. 2015. Metode Penelitian Kombinasi (Mix Methods). Bandung: Alfabeta Sugiyono. 2011. Metode Penelitian Kuantitatif Kualitatif dan R\&D. Alfabeta. 
Veithzal, Rivai. 2004. Manajemen Sumber Daya Manusia Untuk Perusahaan. Jakarta, PT. Raja Grafindo Persada. 